\title{
PEMANFAATAN PERTANIAN RUMAH TANGGA DENGAN TEKNIK VERTIGAN DAMBO (VERTIKULTUR ORGANIK DALAM BOTOL)
}

\author{
Muhammad Rosyid Ridho \\ UIN Sunan Gunung Djati Bandung \\ Email: muhammadrosyid726@gmail.com
}

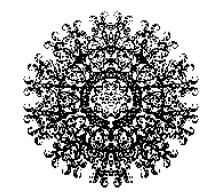

\begin{abstract}
ABSTRAK
Kegiatan masyarakat ini bertujuan untuk memanfaatkan pekarangan rumah warga Kelurahan Sanga Sanga Muara, Kecamatan Sanga Sanga, Kabupaten Kutai Kartanegara sebagai optimalisasi fungsi lahan dan pengurangan sampah botol plastik. Dengan teknik budidaya tanaman sayuran secara vertikultur dalam botol. Kurang terpenubinya kebutuban sayuran dan melimpahnya sampah botol plastik menjadi permasalahan yang ada di Kelurahan Sanga Sanga Muara. Dari permasalahan itu, pertanian dengan metode vertikultur dalam botol (vertigan dambo) menjadi solusi bagi masyarakat. Metode pelaksanaan kegiatan ini yaitu melalui tiga tahap yakni tahap pesiapan, pelaksanaan dan evaluasi. Hasil dari pelaksanaan kegiatan ini yaitu adanya perubaban positif terbadap sikap warga tentang kesadaran mereka dalam menanam sayuran ditengah kesibukan mereka sebagai nelayan dan pekerja tambang.
\end{abstract}

Kata Kunci: Pekarangan Rumah, Teknik Budidaya Tanaman, Vertikultur

\section{ABSTRACT}

This community activity aims to utilize the yard of the houses of residents of Sanga Sanga Muara Village, Sanga Sanga District, Kutai Kartanegara Regency as an optimization of land functions and reduction of plastic bottle waste. With the technique of cultivating vegetable plants verticulture in bottles. Lack of fulfillment of vegetable needs and the abundance of plastic bottle waste becomes a problem in Sanga Sanga Muara Village. From that problem, agriculture with verticulture method in bottles (vertigan dambo) becomes a solution for the community. The method of implementing this activity is through three stages, namely the stage of preparation, implementation and evaluation. The result of this activity is a positive change in the attitude of citizens about their awareness in growing vegetables amid their busy lives as fishermen and mine workers.

Keywords: Home Yard, Plant Cultivation Techniques, Verticulture 


\section{Indonesian Engagement Journal Vol. 2 No. 2 Desember 2021}

\section{PENDAHULUAN}

Sayur merupakan kebutuhan masyarakat yang sangat penting. Dalam sayuran terdapat beberapa kandungan yang baik untuk tubuh, diantaranya adalah vitamin, mineral, serat makanan dan zat-zat phytochemical yang berguna bagi tubuh. Vitamin utama dalam sayur yang sukar untuk digantikan oleh makanan lain adalah vitamin c, betakaroten yang berguna sebagai anti oksidan dan asam folat. ${ }^{1}$ Dampak bagi kekurangan sayuran tentu akan berakibat fatal bagi tubuh. Kandungan serat dalam sayuran sangat berguna untuk memperlambat penyerapan gula, sehingga kadar gula dalam tubuh stabil hal tersebut dapat mencegah timbulnya penyakit diabetes melitus dan penyakit pembuluh darah lainnya. Selain itu, kekurangan sayuran juga dapat menyebabkan penyakit gangguan pencernaan yang akibat terburuk dari penyakit ini adalah kematian. ${ }^{2}$ Berdasarkan data dari organisasi kesehatan dunia WHO kurangnya konsumsi buah dan sayur dapat mengakibatkan terserangnya kanker gastrointestinal sebesar 19\%, peenyakit jantung iskemik 30\% serta penyebab stroke $11 \%$ di seluruh dunia, dan sekitar 2,7 juta (4,9\%) kematian dapat disebabkan karena kurangnya konsumsi buah dan sayur. ${ }^{3}$

Salah satu daerah yang masih kekurangan pasokan sayuran adalah Kelurahan Sanga Sanga Muara yang terletak di Kecamatan Sanga-Sanga Kabupaten Kutai Kartanegara. Kelurahan Sanga Sanga Muara memiliki kepadatan penduduk terbanyak kedua di Kecamatan Sanga Sanga setelah Kelurahan Sanga sanga Dalam dengan jumlah penduduk 3470 orang yang terbagi dalam 967 KK dan dalam 11 RT yang ada di Kelurahan Sanga Sanga Muara. Adapun masalah yang dihadapi penduduk Kelurahan Sangasanga Muara adalah bahwa jenis tanaman holtikultura khususnya sayuran masih jarang dilakukan proses budidayanya oleh masyarakat sekitar. Sehingga untuk memenuhi kebutuhan sayur sayuran dengan cara membeli di pasar ataupun tukang sayur. Akan tetapi jarak yang ditempuh untuk membeli sayur tersebut memakan waktu sangat lama sekitar 45 menit dari Kelurahan

${ }^{1}$ Fitriyanii Arbie, "Pengetahuan Gizi Berhubungan Dengan Konsumsi Sayuran dan Buah Pada Remaja," Health and Nutrition Journal 1 (2015): 25.

2 Ni Luh Widani, "Penyuluhan Pentingnya Konsumsi Buah dan Sayur pada Remaja di Sos Desataruna Jakarta," Jurnal Patral 1, no. 1 (2019): 59.

3 World Health Organzation, The World Health Report 2002Reducing Risk, Promoting Healty Life (Geneva: WHO Press, 2002), 60-61. 


\section{Indonesian Engagement Journal Vol. 2 No. 2 Desember 2021}

Sanga Sanga Muara dan jika menungu penjual sayur pun harus menunggu sampai siang itu pun belum tentu ada tukang sayur yang lewat. Suplay sayuran dari kelurahan Sanga Sanga Muara adalah dari Kota Samarinda. Tak heran jika keterlambatan sayuran itu sudah merupakan hal yang wajar mengingat jarak antara Samarinda dan Sanga Sanga Muara sangat jauh.

Selain permasalahan mengenai ketidakmampuan masyarakat dalam memenuhi kebutuhan sayuran, potensi pekarangan rumah atau lahan di sekitar rumah kurang dimanfaatkan oleh masyarakat. Sehingga pekarangan rumah terlihat begitu mangkrak dan tidak ada tanaman yang menghiasi. Satu lagi masalah yang muncul di Kelurahan Sanga Sanga Muara yakni mengenai maraknya sampah botol plastik air mineral yang tercecer di pekaragan, muara sungai, akses jalan dan tempat tempat lain. Botol plastik ini bukan hanya dari sampah masyarakat sekitar Sanga Sanga Muara akan tetapi juga sampah kiriman dari daerah lain.

Solusi dari permasalahan yang ada di masyarakat Kelurahan Sanga Sanga Muara adalah dengan peningkatan kapasitas dan pendampingan dalam pemanfaatan lahan melalui budidaya tanaman sayur dengan metode vertikultur organik dalam botol. dengan menyusun tanaman secara bertingkat dari bawah keatas atau sebaliknya. Teknik vertikultur bisa dilakukan menggunakan berbagai macam wadah (tempat media tanam) seperti pipa paralon, botol bekas, pot, polybag atau wadah lainnya tergantung kreatifitas. ${ }^{4}$ Pada dasarnya teknik bercocok tanam vertikultur tidak jauh berbeda dengan bercocok tanam konvensional, hanya cara meletakkan atau menyusun tanaman saja yang berbeda. Pertanian rumah tangga saat ini sedang banyak dilakukan, namun persepsi masyarakat terkait ilmu, tempat dan waktu menjadikan kendala untuk membuat pertanian rumah tangga.

Berangkat dari hal di atas, pengabdian ini bertujuan untuk memberikan pelatihan dan pembinaan kepada masyarakat untuk memanfaatkan pekarangan rumah dan sampah-sampah botol plastik sebagai media tanaman. Pengabdian ini berfokus pada

\footnotetext{
4 Dyah Pikanthi Diwanti, "Pemanfaatan Pertanian Rumah Tangga (Pekarangan Rumah) Dengan Teknik Tanaman Sayuran Secara Vertikultur," Martabe: Jurnal Pengabdian Masyarakat 1, no. 3 (2018): 103.
} 
Indonesian Engagement Journal

Vol. 2 No. 2 Desember 2021

metode menanam sayur dengan media botol atau biasa disebut dengan Vertigan Dambo (vertikultur organik dalam botol). Dengan adanya pelatihan ini, masyarakat Kelurahan Sanga Sanga Muara diharapkan dapat memenuhi kebutuhan sayur keluarganya tanpa harus menunggu pasokan sayur dari luar daerah. Sehingga ketersediaan sayuran keluarga dapat terpenuhi sebagai penyeimbang gizi dalam makanan.

\section{METODE}

\section{Tempat dan Waktu}

Kegiatan pengabdian ini dilaksanakan pada hari Kamis, 8 Agustus 2019 di balai pertemuan Kelurahan Sanga Sanga Muara, Kecamatan Sanga Sang, Kabupaten Kutai Kartanegara. Dimulai pada pukul 14.00 dan berakhir pada pukul 17.00..

\section{Metode Pelaksanaan Kegiatan}

Pengabdian masyarakat ini menggunakan metode penyuluhan dan demonstrasi, dan dilakukan dalam tiga tahap yaitu:

1. Tahap persiapan, tahap ini meliputi persiapan narasumber, persiapan penentuan peserta, persiapan tempat dan peralatan serta bahan-bahan lainnya.

2. Tahap Pelaksanaan, tahap ini merupakan presentasi dan penyuluhan yang dilakukan oleh narasumber serta dilanjutkan dengan praktik demonstrasi.

3. Tahap evaluasi, yakni memberikan tindak lanjut atas penyuluhan yang sudah diberikan dengan melalui pendampingan di masyarakat.

\section{HASIL DAN PEMBAHASAN}

Dewasa ini, tidak mudah melakukan kegiatan di lahan yang luas untuk melakukan bercocok tanam, hal tersebut dikarenakan banyak faktor diantaranya kurang suburnya lahan, mahalnya harga tanah sserta sempitnya pekarangan rumah. Kendala yang dihadapi masyarakat Kelurahan Sanga Sanga Muara sempitnya lahan dan kurang suburnya lahan di sekitar masyarakat. Hal tersebut dikarenakan sebagian besar masyarakat tinggal di atas sungai Mahakam. Selain itu, masyarakat juga kurang memiliki inisiatif dan kereatifitas 


\section{Indonesian Engagement Journal \\ Vol. 2 No. 2 Desember 2021}

dalam mengelola sampah-sampah botol plastik yang berserekan. Berdasarkan observasi awal yang telah dilakukan di PKK Kelurahan Sanga Sanga Muara didapatkan permasalahan sebagai berikut:

1. Kurangnya keterampilan ibu-ibu PKK dan masyarakat sekitar dalam memanfaatkan botol bekas plastik yang sangat melimpah di Kelurahan Sanga Sanga Muara.

2. Minimnya lahan pekarangan rumah karena banyak masyarakat yang tinggal di atas sungai Mahakam dengan rumah panggungnya

3. Kurangnya motivasi dan semangat membuat kreatifitas dengan menggunakan botol bekas plastik

4. Kurangnya memanfaatkan waktu luang untuk membuat kreatifitas

Dari kendala di atas, pengabdian ini akan memberikan penyuluhan tentang vertigan dambo (vertikultur organik dalam botol) yaitu menanam sayur dengan teknik vertikular merupakan sistem budidaya pertanian yang dilakukan secara vertikal atau bertingkat dengan media yang beragam seperti botol, paralon dan bambu. Teknik yang digunakan sangat sederhana namun butuh ketelatenan dalam pemeliharaan. Beberapa jenis sayuran yang dapat ditanam dalam budidaya ini yaitu selada, sawi, bayam dan kangkunng. media tanamnya yakni campuran antara tanah, pasir dan pupuk kandang atau kompos dengan perbandingan yang sama atau bisa juga menggunakan sekam. Budidaya ini memiliki banyak keuntunngan diantaranya yaitu Efisiensi dalam penggunaan lahan, Mudah dalam pemeliharaan, Penghematan penggunaan pupuk, dapat dipindahkan dengan mudah, hemat air serta menambah estetikan di pekarangan sekitar. ${ }^{5}$

Dalam kegiatan pengabdian ini di bagi menjadi tiga tahapan yaitu tahap persiapan, pelaksanaan dan evaluasi.

1. Tahap perencanaan meliputi

a. Persiapan narasumber

5 Asropah, "Pemanfaatan Barang Bekas Botol Plastik Dalam Pembuatan Vertical Garden," EDimas education Jurnal Pengabdian Kepada Masyarakat 07, no. 02 (2016): 15. 


\section{Indonesian Engagement Journal Vol. 2 No. 2 Desember 2021}

Dalam tahap ini seluruh tim melakukan diskusi untuk menentukan narasumber yang untuk kegiatan penyuluhan ini. Setelah diskusi selesai diputuskan yang menjadi pemateri adalah penyuluh pertanian dari Kabupaten Kutai Timur. Pemateri yang dihadirkan adalah Citra Dewi yang merupakan penyuluh pertanian dari Dinas Pertanian Kabupaten Kutai Timur.

b. Penentuan peserta.

Setelah koordinasi dengan bapak lurah Muliyadi Sugiyansah didapat kesimpulan bahwa yang menjadi peserta kegiatan ini adalah ibu-ibu PKK Kelurahan Sanga Sanga Muara dan perwakilan RT setempat.

c. Persiapan tempat, peralatan dan bahan

Pelatihan ini dilaksanakan di aula Kelurahan Sanga-Sanga Muara yang mampu menampung kurang lebih 50 peserta yang meliputi ibu-ibu PKK Sanga Sanga Muara dan perwakilan RT setempat. Untuk peralatan yang dibutuhkan dalam penyuluhan ini diantara yaitu botol bekas, tanah, kompos, dan benih sayuran yang sebelumnya sudah di semai kan oleh tim beberapa hari sebelumnya.

2. Tahap pelaksanaan

a. Tahap sosialisasi

Sosialisasi, Sosialisasi dilaksanakan untuk menambah wawasan dan ilmu masyarakat setempat bahwa terdapat potensi yang dapat dikembangkan, baik dari segi SDA maupun SDM-nya. Sosialisasi juga dilaksanakan untuk mengatasi permasalahan yang ada di Kelurahan Sanga Sanga Muara diantaranya kurangnya minat masyarakat memanfaatkan pekarangan rumah. Sosialisasi berupa sosialisasi pembuatan vertikultur untuk budidaya tanaman sayuran target sasaran utamanya adalah Ibu-Ibu Kelurahan Sanga Sanga Muara. Selain itu, dalam sosialisasi ini juga dijelaskan pentingnya mengkonsumsi sayur sebagai bentuk kesimbangan gizi dalam makanan.

b. Tahap Demonstrasi

Kegiatan demonstrasi dilakukan setelah penyuluhan selesai disampaikan. Dalam kgiatan demonstrasi ini, narasumber meriview kembaan baku yang 


\section{Indonesian Engagement Journal}

Vol. 2 No. 2 Desember 2021

digunakan. Selain itu, disampaikan pula tahapan proses yang dilakukan dalam pembuatan vertikultur organik dalam botol. Tahap pertama yaitu, membuat media tanam dengan mengumpulkan botol-botol bekas yang kemudian dilubangi bagian bawah nya atau sisi sisi nya. Tahap kedua yaitu, botol-botol bekas tadi diisi Media tanamnya berupa tanah, sekam dan pupuk kandang serta kompos sebagai media tanam. Tahap ketiga yaitu menanam bibit sayur yang sebelumnya sudah dilakukan pembibitan oleh panitia. Penanaman bibit dilakukan pada tanaman yang sudah memiliki 2-3 helai daun.Tahap keempat sekaligus tahap terakhir yaitu menyusun hasil tanaman tadi di tembok atau pun di tempat lain dengan posisi vertikal.

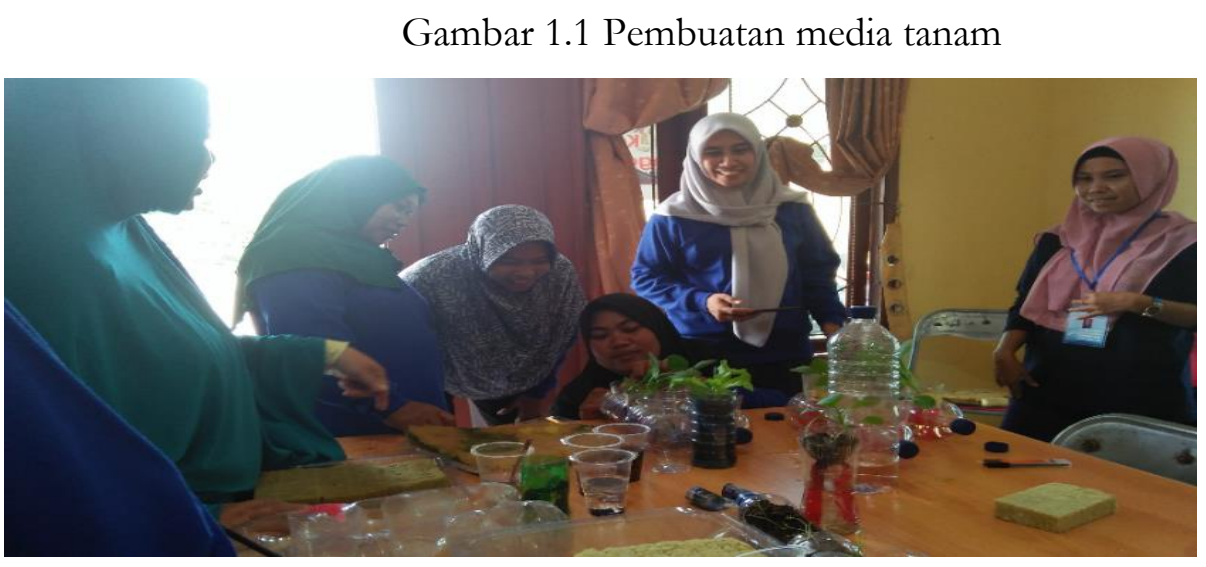

Gambar 1.2 Pengisisn media tanam (tanah, kompos, sekam dll)

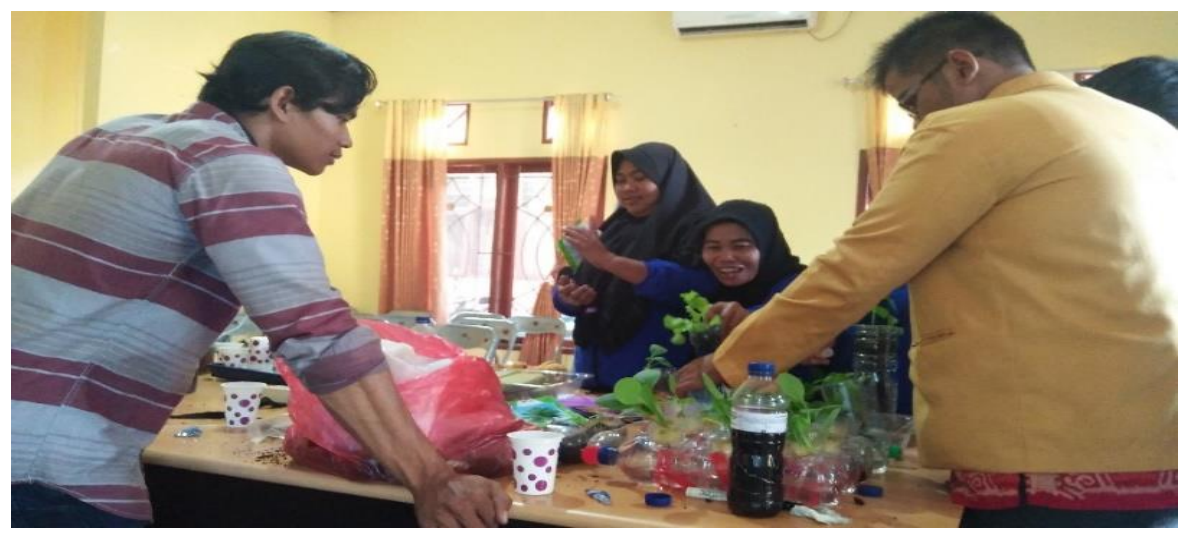

Gambar 1.3 Menanam sayuran yang sudah disiapkan 


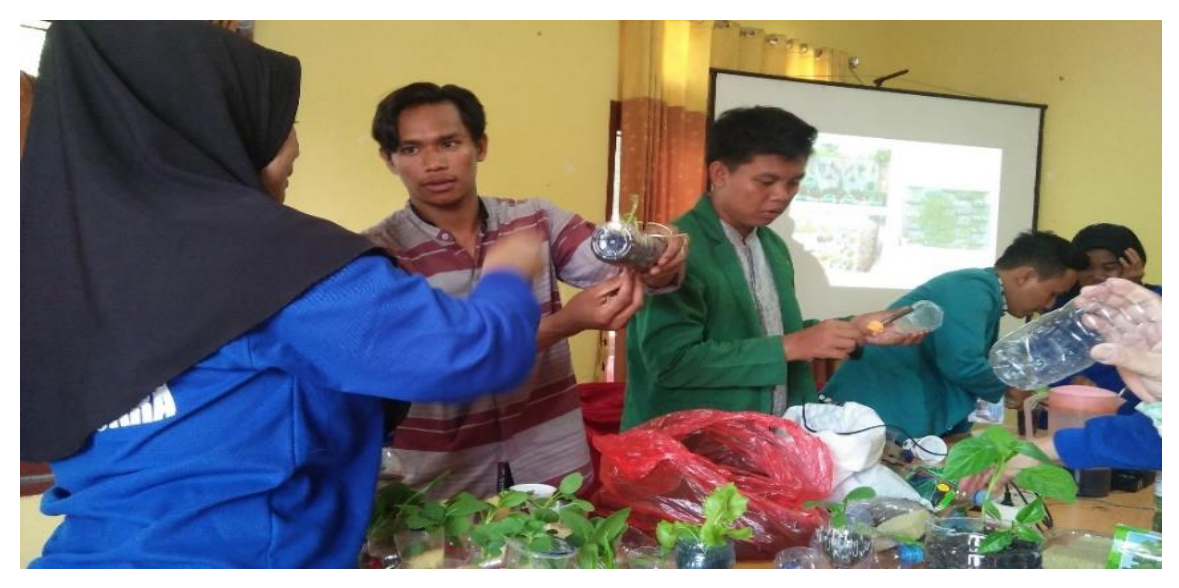

Gambar 1.4 Penyusunan tanaman di media vertikal

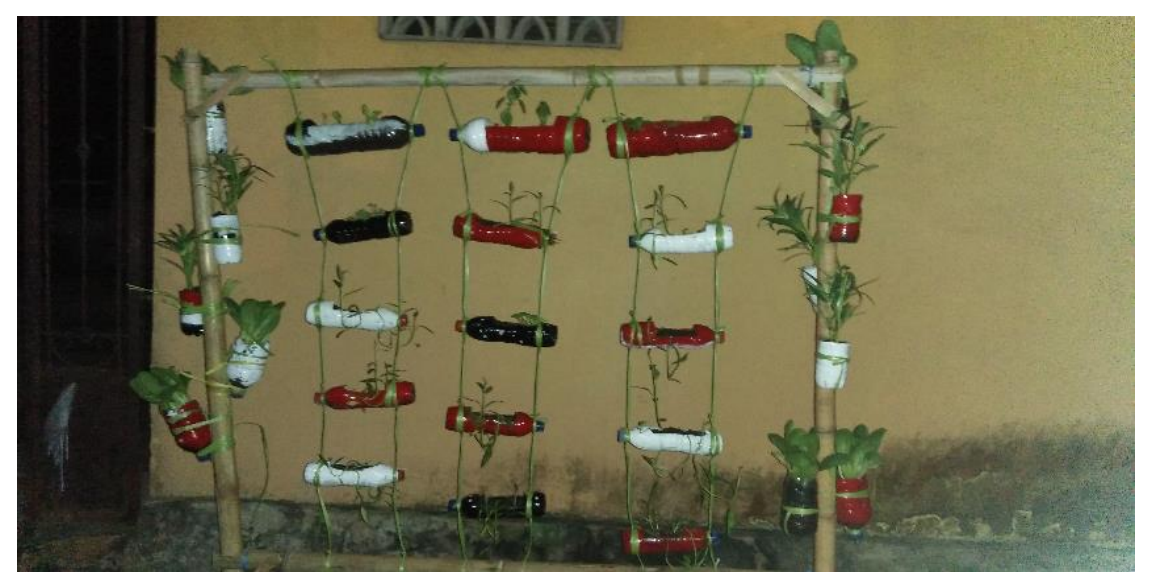

3. Tahap evaluasi

Di akhir acara, para peserta diberikan benih secara gratis dengan tujuan agar dapat ditanam di rumah masing-masing. Selanjutnya, tindak lanjut dari kegiatan pelatihan menanam dengan metode vertikultur dambo adalah dilakukannya Pendampingan. Pendampingan dilakukan dalam pengelolaan tanaman sayuran yang untuk selanjutnya bisa dilakukan secara mandiri. Jenis tanaman yang ditanam Ibu-Ibu PKK dan beberapa masyarakat Kelurahan Sanga Sanga Muara adalah sayur sayuran mulai dari sawi, kangkung, selada, kemangi dan sebagainya. Evaluasi dalam kegiatan ini bertujuan untuk penyempurnaan program yang telah dilaksanakan apakah sudah sesuai dengan capaian yang diharapkan atau belum. 


\section{Indonesian Engagement Journal}

Vol. 2 No. 2 Desember 2021

\section{KESIMPULAN}

Dari rangkaian pelaksanaan kegiatan pemanfaatan pekarangan rumah, ada beberapa indikasi keberhasilan dari program tersebut. Di antaranya sikap warga yang menunjukan perubahan positif yaitu adanya peningkatan kesadaran warga yang mayoritas sebagai nelayan dan pekerja di tambang akan pentingnya pemanfaatan pekarangan untuk penanaman tanaman sayuran secara vertikultur, antusiasme warga dan kesadaran untuk pemanfaatan lahan pekarangan, kemudian warga juga memiliki kesadaran mengenai pemanfaatan banyaknya limbah botoh plastik. Sehingga dapat mengurangi limbah tersebut. Selain itu menghasilkan suatu produk panen tanaman yang lebih bersih dan higienis. Berdasarkan program ini menunjukan bahwa kebutuhan pangan sebenarnya bisa dipenuhi dari pemanfaatan pekarangan rumah untuk peningkatan kesejahteraan masyarakat dan adanya efisiensi kebutuhan rumah tangga.

\section{DAFTAR PUSTAKA}

Arbie, Fitriyanii. "Pengetahuan Gizi Berhubungan Dengan Konsumsi Sayuran dan Buah Pada Remaja." Health and Nutrition Journal 1 (2015): 23-31.

Asropah. "Pemanfaatan Barang Bekas Botol Plastik Dalam Pembuatan Vertical Garden.” E- Dimas education Jurnal Pengabdian Kepada Masyarakat 07, no. 02 (2016).

Diwanti, Dyah Pikanthi. "Pemanfaatan Pertanian Rumah Tangga (Pekarangan Rumah) Dengan Teknik Tanaman Sayuran Secara Vertikultur.” Martabe: Jurnal Pengabdian Masyarakat 1, no. 3 (2018).

Widani, Ni Luh. "Penyuluhan Pentingnya Konsumsi Buah dan Sayur pada Remaja di Sos Desataruna Jakarta.” Jurnal Patral 1, no. 1 (2019): 57-68.

World Health Organzation. The World Health Report 2002Reducing Risk, Promoting Healty Life. Geneva: WHO Press, 2002. 